\title{
Bajoprosopon piardi n. gen. and sp. from the Middle Jurassic of France, with a revised diagnosis of the family Prosopidae von Meyer, 1860 (Brachyura, Podotremata) and notes on the availability of names introduced by Hermann von Meyer $(1835,1857)$
}

\author{
Barry W.M. van Bakel, Lionel Maerten, John W.M. Jagt, and René H.B. Fraaije
}

\begin{abstract}
The earliest known brachyurans, or true crabs, are of Early and Middle Jurassic age. In general, they are rare and known from either a single or a few specimens only. Here we record a new genus and species of homolodromioid crab of Bajocian (early Middle Jurassic) age from Calvados (northwest France), based on a unique dorsal carapace. On the basis of carapace morphology, this is here assigned to the primitive family Prosopidae, but distinguished from other members due to the carapace grooves and tubercles and conspicuously large orbital fossae.
\end{abstract}

Barry W.M. van Bakel, Department of Earth Sciences, Faculty of Geosciences, Utrecht University, Budapestlaan 4, 3584 CD Utrecht, the Netherlands, and Oertijdmuseum, Bosscheweg 80, 5283 WB Boxtel, the Netherlands. b.w.m.vanbakel@uu.nl (orcid.org/0000-0002-0414-1041) Lionel Maerten, 3 Impasse du Moulin, 14114 Ver sur Mer, France. lionelmaerten@hotmail.fr John W.M. Jagt, Natuurhistorisch Museum Maastricht, de Bosquetplein 6-7, 6211 KJ Maastricht, the Netherlands. john.jagt@maastricht.nl (orcid.org/0000-0001-6216-1991)

René H.B. Fraaije, Oertijdmuseum, Bosscheweg 80, 5283 WB Boxtel, the Netherlands.

info@oertijdmuseum.nl (orcid.org/0000-0002-3465-1093)

Keywords: Mesozoic; Bajocian; "Oolithe ferrugineuse de Bayeux“; new taxa; Homolodromioidea; Calvados; France, crab

Submission: 27 February 2021. Acceptance: 3 August 2021.

http://zoobank.org/AFFE731B-EE97-441F-BBCD-32B276A61DDD

van Bakel, Barry W.M., Maerten, Lionel, Jagt, John W.M., and Fraaije, René H.B. 2021. Bajoprosopon piardi n. gen. and sp. from the Middle Jurassic of France, with a revised diagnosis of the family Prosopidae von Meyer, 1860 (Brachyura, Podotremata) and notes on the availability of names introduced by Hermann von Meyer (1835, 1857). Palaeontologia Electronica, 24(2):a26. https://doi.org/ $10.26879 / 1153$

palaeo-electronica.org/content/2021/3427-new-bajocian-crab-from-france

Copyright: August 2021 Paleontological Society.

This is an open access article distributed under the terms of Attribution-NonCommercial-ShareAlike 4.0 International (CC BY-NC-SA 4.0 ), which permits users to copy and redistribute the material in any medium or format, provided it is not used for commercial purposes and the original author and source are credited, with indications if any changes are made. creativecommons.org/licenses/by-nc-sa/4.0/ 


\section{INTRODUCTION}

The oldest brachyurans known to date, both of Pliensbachian (Early Jurassic) age, are Eocarcinus praecursor Withers, 1932 from Yorkshire (United Kingdom) and Eoprosopon klugi Förster, 1986 (Förster, 1986; Jagt et al., 2015) from Bavaria (southern Germany). The taxonomic status of the former and the question whether or not it belongs to the Brachyura, in particular, have been addressed and debated on several occasions (Withers, 1932; Glaessner, 1933; Förster, 1979, 1985; Krobicki and Zatoń, 2008; Schweitzer and Feldmann, 2010; Guinot, 2019; Luque et al., 2019). Recently, Scholtz (2020) has discussed the morphology of Eocarcinus praecursor in detail and concluded that it was a stem-group brachyuran. The sole specimen of Eoprosopon klugi on record was re-examined by Haug and Haug (2014), who assigned it to the superfamily Homolodromioidea Alcock, 1900.

Crabs rank amongst the commonest faunal elements in Upper Jurassic deposits, especially in reefs and reef-like structures, but during the Middle Jurassic, they were comparatively rare (Müller et al., 2000; Krobicki and Zatoń, 2016). Subsequent to the Pliensbachian Stage, the next record of brachyuran crabs is from the Bajocian Stage, from which only six species have so far been described. Seen in this light, every crab record of this age is of major importance and should be described and illustrated. Bajocian crabs have been recorded mainly from France and England, but there are also records from Germany and Poland, as follows:

- Tanidromites maerteni Fraaije, Van Bakel, Guinot, and Jagt, 2013, from the lower upper Bajocian (niortense ammonite Zone) of Maizet, Calvados (northwest France). This form is slightly older than the new species described herein and currently constitutes the oldest member of the family Tanidromitidae Schweitzer and Feldmann, 2008 (Fraaije et al., 2013).

- Tanidromites richardsoni (Woodward, 1907) (as Prosopon Richardsoni); the holotype is of earliest Bathonian (Middle Jurassic) age (see Fraaije et al., 2013), but there are two additional, older records from Somerset (United Kingdom), both from the Upper Coral Beds (parkinsoni ammonite Zone, truellei ammonite Subzone; upper upper Bajocian) (see Withers, 1951; Donovan, 1962). Schweigert and Koppka (2011) described a single specimen of T. richardsoni from coeval levels (Sengenthal Formation, Parkinsonien-Oolith Member) at
Göllersreuth near Thalmässing (Franconia, southern Germany).

- Tanidromites muelleri Krobicki and Zatoń, 2016, from uppermost Bajocian deposits (parkinsoni ammonite Zone, bomfordi ammonite Subzone) in central Poland, has been recorded on the basis of fairly numerous specimens. The palaeoenvironment inhabited was characterised as a shallow-water, oyster patch reef.

- Pithonoton incisus Van Straelen, 1925 from reefal facies at May-sur-Orne, Calvados (northwest France). On the basis of biostratigraphical assessments of Bajocian deposits in Calvados (Pavia and Martire, 2010; Pavia et al., 2013, 2015), this facies corresponds to the Calcaires à Spongiaires Formation of the uppermost Bajocian (so-called 'zone à Stomechinus bigranularis'), which overlies the grey cherty biomicrite with sponges and glauconite grains (Malière Formation; Aalenian to lower Bajocian) and the 'Oolithe ferrugineuse de Bayeux' Formation (lower-upper Bajocian).

- Planoprosopon major (Hée, 1924) (as Prosopon major), from the same level and locality as Pithonoton incisus (see above). The type material of both these species is lost; no new material has ever been described since.

- Abyssophthalmus hebes (von Meyer, 1840) (as Prosopon hebes), originally described from the lower Bajocian 'Oolithe ferrugineuse inférieure' near Thionville (Lorraine, eastern France). Schweigert (2006) recorded this species from the basal part of the Humphriesi Oolith Formation (upper sauzei [propinquans] ammonite Zone, lower Bajocian) at Wehingen, western Swabia, Germany.

The generic placement of the two last-named species is uncertain and needs to be reassessed. The family Tanidromitidae appears to have formed a prominent component in Middle Jurassic decapod crustacean evolution. Here we add a seventh form: a new genus and species of prosopid from the Bajocian of northwest France.

\section{LOCALITY AND STRATIGRAPHY}

The present specimen originates from the upper Bajocian 'Oolithe ferrugineuse de Bayeux' Formation (OfB) (see also Breton et al., 2020). The outcrop named 'Les Fours à Chaux' (lime kiln), between Croisilles and Les Moutiers-en-Cinglais (Calvados), was described by Pavia et al. (2015). 

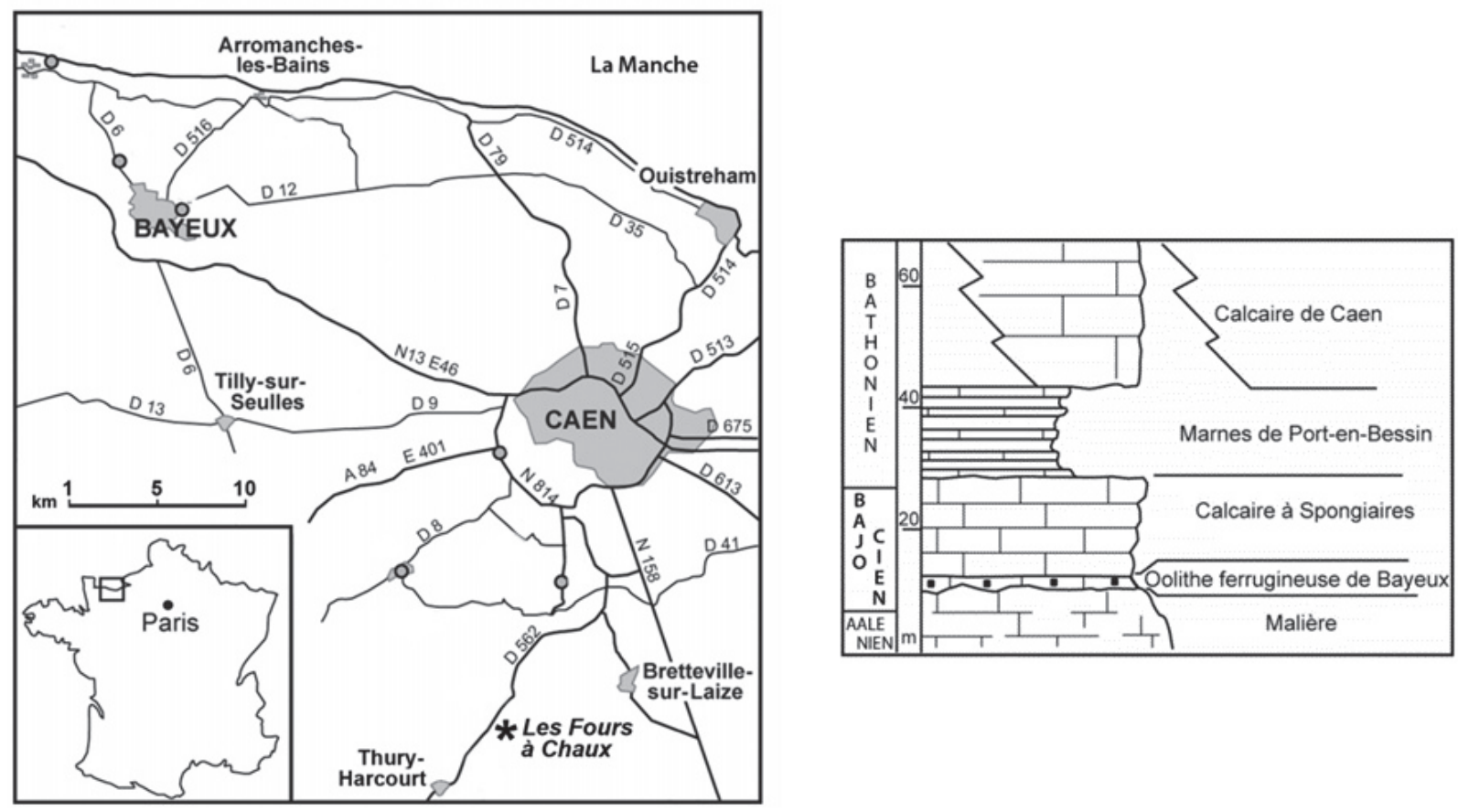

FIGURE 1. Map showing the environs of Caen and Bayeux (northwest France) and the type locality, Les Fours à Chaux (asterisk), of Bajoprosopon piardi n. gen. and sp. The simplified log (right) illustrates the lithology, lithostratigraphical nomenclature and chronostratigraphy (after Pavia et al., 2015).

This exposure (see Figure 1) documents a condensed section with ubiquitous taphonomic reworking; most fossils appear to represent remanié elements that were transported or remobilised before final burial. The crab studied herein comes from the base of 'Level 12' (sensu Pavia et al., 2015, p. 12), which constitutes a bioclastic and oolitic packstone. The oolites at this level are of moderate size $(0.3-0.4 \mathrm{~mm})$; oncoids are abundant. These ferruginous oncoids were part of a reef-like seafloor (Jester, 2017). This level is rich in brachiopods, gastropods and bivalves, with large specimens of Ctenostreon rugosum (Smith, 1817); ammonites are less abundant. In Figure 2, some associated faunal elements are illustrated. Biochronostratigraphically, this level corresponds to the upper garantiana ammonite Zone, dichotoma ammonite Subzone. The marine environment was shallow, and palaeogeographically very close to the Armorican Massif, from which the nearest Bajocian deposit in the entire region is known.

\section{ON THE PUBLICATION DATES OF HERMANN VON MEYER'S KEY PAPERS}

Almost exclusively, authorship of the genus Prosopon is attributed to Hermann von Meyer (1835), while its type species is exclusively quoted as Prosopon tuberosum von Meyer, 1840. How- ever, a generic name can become available only when a species is assigned to it; thus, it is unacceptable that in this particular case the type species was published five years later. In addition, a new generic name must be accompanied by a description or a diagnosis, or an indication such as an illustration or a reference to an illustration (ICZN articles 12.1 and 12.2). Von Meyer did not provide any of such in his 1835 'Mittheilungen' [reports]; instead, he announced that illustrations and descriptions [of prosopid taxa] would be supplied in subsequent work. Indeed, descriptions and illustrations were provided in his 1840 paper, making these names, and thus the genus Prosopon, available. In summary, both the generic name Prosopon and its type species, Prosopon tuberosum, should be ascribed to von Meyer (1840). Prosopon tuberosum was the first species to be described in von Meyer's (1840) paper, but it was not indicated as type; neither it is the sole species of the genus described in that year. If it had been, it would have been considered type species by monotypy. The order of species in any paper does not determine the type species, but Beurlen (1928, p. 146) subsequently designated $P$. tuberosum as type species, making it "type by subsequent designation" (ICZN Article 69.1). 


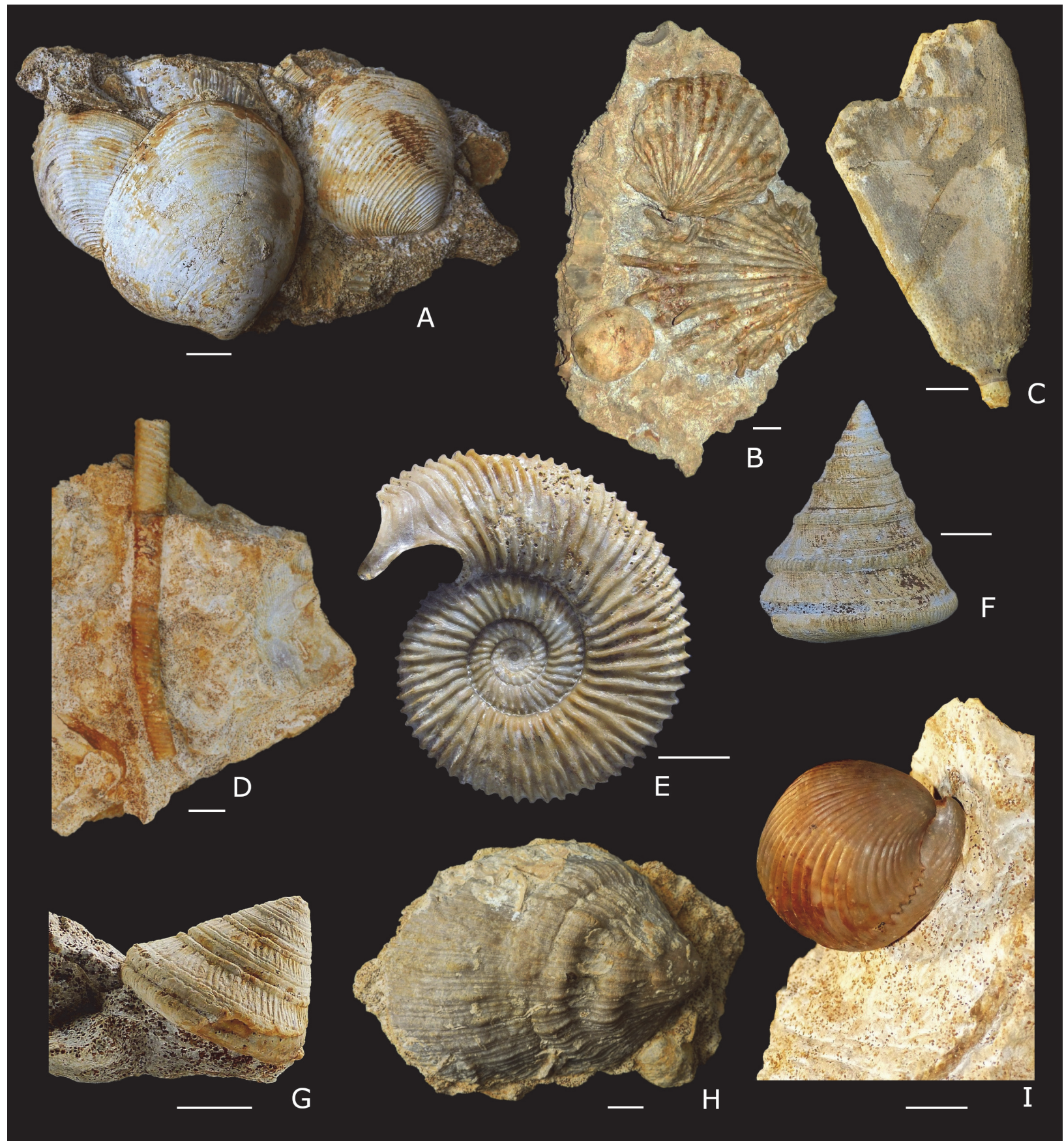

FIGURE 2. Macrofaunal elements associated with Bajoprosopon piardi n. gen. and sp.; upper Bajocian 'Oolithe ferrugineuse de Bayeux' Formation, upper garantiana ammonite Zone, dichotoma ammonite Subzone, 'Les Fours à Chaux', between Croisilles and Les Moutiers-en-Cinglais (Calvados, northwest France). A. Neocrassina obliqua (Lamarck, 1819) and Astarte elegans J. Sowerby, 1816; B. Ctenostreon rugosum (Smith, 1817); C. Dickesicidaris copeoides (Agassiz in Agassiz and Desor, 1847); D. Spiroceras annulatum (Deshayes, 1831); E. Garantiana (Pseudogarantiana) dichotoma (Bentz, 1928); F. Pyrgotrochus elongatus (J. Sowerby, 1818); G. Leptomaria amoena (Deslongchamps, 1848); H. Eopecten velatus (Goldfuss, 1833); I. Sphenorhynchia plicatella (Sowerby, 1825). Collection and photographs: Lionel Maerten. Scale bars equal $10 \mathrm{~mm}$. 
In 1857, Hermann von Meyer published a short paper in which he tabulated species of Prosopon von Meyer, 1840, some of which had already been described in his 1840 paper (i.e., P. tuberosum, $P$. hebes, $P$. simplex and $P$. rostratum), while others, as he indicated (1857, p. 555), were to appear in 'extensive work with illustrations' [our translation from German] to be published in the journal Palaeontographica. The latter is his 1860 paper (von Meyer, 1860). Of the new names (thus not the names published by von Meyer in 1840) he listed in the 1857 note, none are accompanied by any description, nor a diagnosis of any sort, and thus do not meet the requirements for being available as new (ICZN 1999, article 12.1). Alternatively, names published prior to 1931 may be accompanied by an indication, rather than a description, such as a reference to a previously published description, or even just an illustration (ICZN 1999, article 12.2), but no such 'indication' is supplied in von Meyer (1857). Thus, the new 1857 names must be considered nomina nuda. As a matter of fact, von Meyer did provide descriptions and illustrations of these species in his later paper (von Meyer, 1860), making these names available. Thus, these need to be listed with the date 1860 , not 1857.

In many recent papers dealing with prosopid crabs, the date for these species has been erroneously noted as 1857 . For instance, Klompmaker et al. (2020) have recently considered Prosopon verrucosum Reuss, 1858 to be a junior synonym of Prosopon aculeatum von Meyer, 1857. However, the specific epithet aculeatum did not become available until 1860, and should thus be considered a junior synonym of verrucosum, instead vice versa. Klompmaker et al. (2020) have also erected a new genus, Europrosopon Klompmaker, Starzyk, Schweigert and Fraaije, 2020, indicating (p. 21) the type species to be "Prosopon aculeatum von Meyer, 1857 (=Prosopon verrucosum Reuss, 1858)". ICZN Article 67.1.2 states that "The name of a type species remains unchanged even when it is a junior synonym or homonym". Therefore, Prosopon aculeatum von Meyer, 1860 (= junior synonym of Prosopon verrucosum Reuss, 1858) should be listed as type species of Europrosopon.

\section{SYSTEMATIC PALAEONTOLOGY}

To denote the repositories of material described and referred to herein, the following institutional abbreviations are used: MAB k. = Oertijdmuseum, Boxtel, the Netherlands; $\mathbf{M N H N}=$ Muséum national d'Histoire naturelle, Paris,
France. We follow the higher classification of the Brachyura advocated by Guinot et al. (2013).

Order DECAPODA Latreille, 1802

Infraorder BRACHYURA Linnaeus, 1758

Section PODOTREMATA Guinot, 1977

Subsection DYNOMENIFORMIA Guinot, Tavares, and Castro, 2013

Superfamily HOMOLODROMIOIDEA Alcock, 1900 Family PROSOPIDAE von Meyer, 1860

Included genera (see Figure 3). Acareprosopon Klompmaker, 2013; Bajoprosopon n. gen.; Europrosopon Klompmaker, Starzyk, Schweigert and Fraaije, 2020; Nipponopon Karasawa, Kato and Terabe, 2006; Prosopon von Meyer, 1840; Protuberosa Schweitzer and Feldmann, 2009 and Rathbunopon Stenzel, 1945.

Diagnosis. Carapace elongated, longer than wide, suboval in outline, widest at posterior branchial region, may be constricted at epibranchial regions; tumid in longitudinal and transverse sections, lateral margins undefined, blunt; hepatic and epibranchial margin may be developed into spine or tubercle. Carapace tripartite by well-separated, complete, distinct cervical, and branchial grooves. Cervical groove wide, divided into three arcs; branchial grooves at steeper angle. Fronto-orbital margin wide, front wide, projected beyond orbits, subtrapezoidal, about one-third of maximum carapace width; orbital margin oblique to subhorizontal, with two coarse, shallow notches; orbital fossae large, subdivided by arched rim, orbits anteriorly and weakly anterolaterally directed. Anterior carapace regions usually inflated, mesogastric region completely delineated, with large, broadly triangular base; protogastric region not completely subdivided by oblique groove; cardiac region well defined, inverted triangular, completely delineated, urogastric region as distinct low rectangle. Posterior margin sinuous or W-shaped (or 'biconvex'), occupying entire carapace width. Dorsal carapace surface densely granular, central and anterior regions may have low nodes or tubercles. Elements other than carapace are unknown.

Remarks. Three species previously assigned to Prosopon, namely $P$. abbreviatum Schweitzer and Feldmann, 2009, P. verrucosum [= P. aculeatum] and $P$. barbulescuae Schweitzer, Feldmann, Lazăr, Schweigert and Franţescu, 2018, have recently been reassigned to a new genus, Europrosopon, by Klompmaker et al. (2020). These authors also argued that the orbital construction in Prosopon, Europrosopon, and Rathbunopon was less unique than previously thought by Schweitzer et al. (2012, 2018, pp. 326, 327); we concur. The diagnosis 


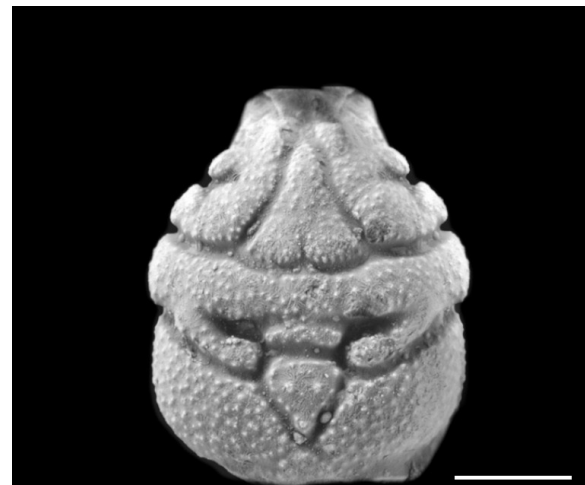

A: Europrosopon

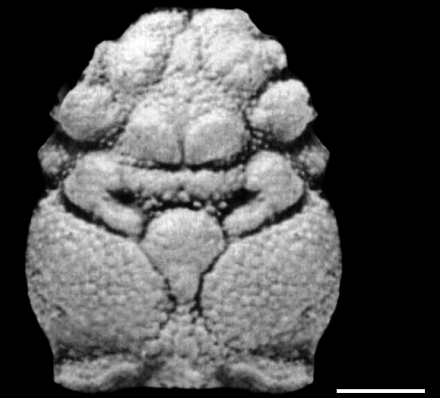

D: Protuberosa

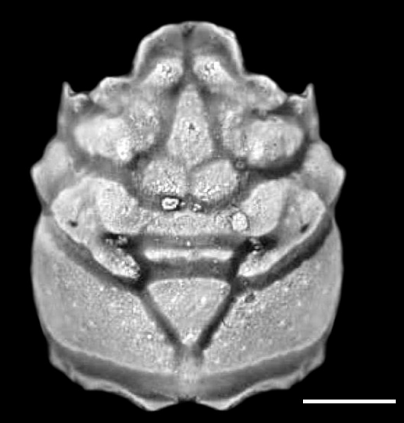

B: Rathbunopon

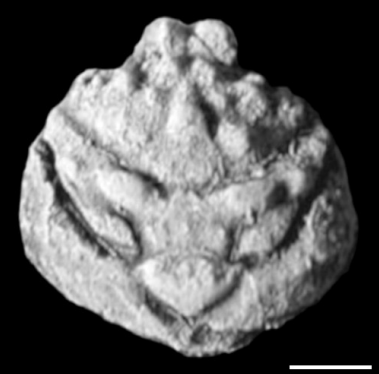

E: Nipponopon

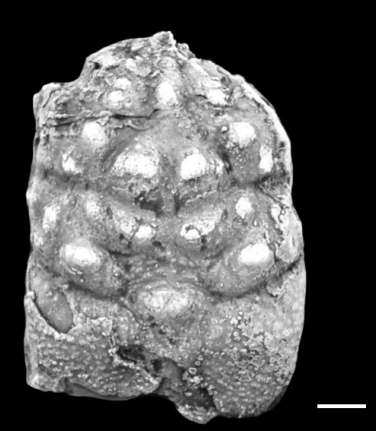

C: Bajoprosopon

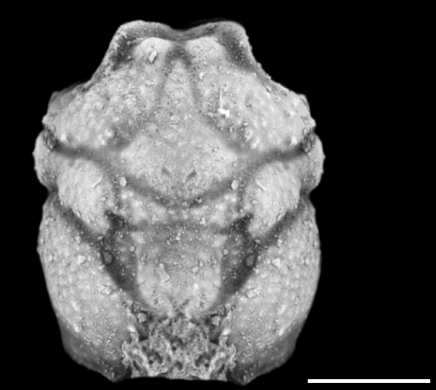

F: Acareprosopon
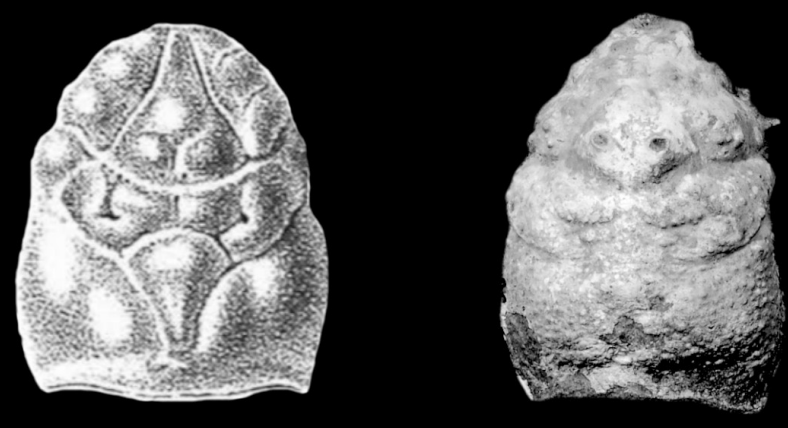

G: Prosopon

FIGURE 3. Composition of the family Prosopidae, as considered herein. A. Europrosopon (E. verrucosum), reconstructed after Klompmaker et al. (2020: figure. 11E). B. Rathbunopon (R. obesum), reconstructed after Klompmaker et al. (2011: figure 3C). C. Bajoprosopon n. gen. (B. piardi n. gen. and sp.). D. Protuberosa (P. protuberosa), reconstructed after Wehner (1988: PI. 1, figure 3). E. Nipponopon (N. hasegawai), reconstructed after Karasawa et al. (2006: figure 1A). F. Acareprosopon (A. bouvieri). G. Prosopon ( $P$. tuberosum, left drawing after von Meyer, $1840 ; P$. mammillatum, right photograph). Scale bars equal $2 \mathrm{~mm}(A-F)$ or $5 \mathrm{~mm}(\mathrm{G})$.

supplied by Schweitzer and Feldmann (2009, p. 65 ) is outdated and based upon a different composition; Fraaije et al. (2013, p. 252) subsequently remarked that the diagnoses of the families Proso- pidae and Tanidromitidae were not sufficiently diagnostic. Klompmaker et al. (2020, p.19) did remark on the Prosopidae, but failed to provide a 
novel diagnosis. Thus, a new diagnosis is presented here (see above).

In recent years, Laeviprosopon has generally been included in the Prosopidae (Schweitzer and Feldmann, 2008, p. 274; Guinot, 2019, p. 774; Klompmaker et al., 2020, p. 19; Starzyk, 2020, p. 10). Here, we exclude it from that family, because it possesses a linea homolica (compare Patrulius, 1966, Collins and Wierzbowski, 1985; N. Starzyk and colleagues, work underway; BWMvB, pers. obs.), a weakly projecting trifurcate front, a nonsinuous, arched concave posterior margin, and undefined orbits (the cornea resting on the dorsal carapace surface). In addition, Laeviprosopon usually has a complete oblique groove that subdivides the protogastric region. The genus is here interpreted as an early representative of the superfamily Homoloidea, and thus excluded from the Homolodromioidea, adopting the views expressed by several previous authors (e.g., Patrulius, 1966; Collins and Wierzbowski, 1985). This fact is the subject of further study (N. Starzyk and colleagues, work under way).

Acareprosopon, from the upper Albian of Navarra (northern Spain), has a rostrum with wide, upturned extensions, and a strongly downturned tip, which is developed into a pointed triangular front. At present, it is unclear if other members of the Prosopidae also had such a downturned tip. The orbital fossae in Acareprosopon are large, anterolaterally directed, with a median arched rim; it thus documents the configuration that is typical of members of the Prosopidae.

Taxonomic placement of the ancient, monospecific genera Homolus Eudes-Deslongchamps, 1835 and Eoprosopon Förster, 1986 is difficult and currently not unambiguous. The available material of these taxa is severely limited and rather poorly preserved; in addition, coeval brachyurans are either missing or extremely rare. Eoprosopon was studied in detail by Haug and Haug (2014), who concluded that it belonged to the superfamily Homolodromioidea. At first sight, the carapace of Eoprosopon is quite similar to that of members of the Prosopidae. In general, Eoprosopon would fit our new diagnosis of the family, but there are some differences. For example, the cervical groove in Eoprosopon is not formed by three arcs, such as in members of the Prosopidae, but takes the form of a wide, continuous ' $V$ ' such as in homolodromiids. The basal part of the mesobranchial region is clearly outlined in prosopids, but weakly defined in Eoprosopon. The branchial groove in Eoprosopon is parallel to the cervical groove (as in homolo- dromiids) and unlike the more steeply angled branchial groove seen in prosopids. The front in Eoprosopon is not well preserved, but it does not seem to be prominent, projected and wide as it is in prosopids. Although there is no absolute certainty, we do agree with Haug and Haug (2014) in considering Eoprosopon to be best accommodated in the Homolodromiidae rather than in the Prosopidae, at least for the time being.

Homolus has been placed in the Homolodromiidae (rather than the Prosopidae) by all recent authors (e.g., Guinot, 1995, pp. 164, 265; Schweitzer and Feldmann, 2010, p. 252; Krobicki and Zatoń, 2016, p. 705; Guinot, 2019, p. 766). Homolus has a bifurcate rostrum, which matches that of homolodromiids better than that of prosopids. More importantly, Homolus lacks well-defined orbital fossae, but has undefined orbits instead (see Schweitzer and Feldmann, 2010, figure 2B, $\mathrm{C})$; the eyestalk is protected by the rostral and outer orbital spines, which is the normal condition in the Homolodromiidae. Thus, Homolus does not fit the new diagnosis of the Prosopidae, and we agree with placement in the Homolodromiidae, at least for the time being.

\section{Genus BAJOPROSOPON nov.}

zoobank.org/0F4A9BFA-57EC-4CD0-B6E0-AAE8A75C1DB2

Type species. Bajoprosopon piardi n. sp., the sole species known to date.

Derivation of name. A combination of the Bajocian Stage and the generic name Prosopon, the nominative genus of the Prosopidae.

Diagnosis. Carapace convex in both directions, suboval in outline, longer than wide (L/W ratio 1.4 [excluding rostrum]). Carapace widest in posterior third. Fronto-orbital margin occupying entire anterior carapace margin; orbits conspicuously large, anteriorly directed, with distinct inner orbital rim. Lateral carapace margins rounded, not defined. Carapace subequally tripartite by well-developed, subparallel, widely V-shaped cervical and branchial grooves, both complete and continuing onto lateral carapace flanks. Mesogastric region large, well delineated, with narrow anterior process and large subtriangular posterior portion. Cardiac region relatively small, less than one third of maximum carapace width, diamond shaped. Carapace anterior of branchial groove with coarse, non-central tubercles; posterior branchial region granular.

Remarks. Bajoprosopon n. gen. can be assigned to the Prosopidae with confidence, in displaying all diagnostic features (see above). Of other members of the family, it can be differentiated as follows: 
Bajoprosopon n. gen. differs from Acareprosopon (type: Pithonoton bouvieri Van Straelen, 1944; upper Albian, Navarra, northern Spain) in having a weaker branchial condensation (i.e., cervical and branchial grooves further apart), a branchial groove that is more divergent and subparallel to the cervical groove, regions anterior to branchial groove with low tubercles, a less elongate cardiac region, and lateral margins more equally divided into three portions (vs posterior portion much longer than anterior two portions in Acareprosopon).

Bajoprosopon n. gen. differs from Europrosopon (type: Prosopon verrucosum Reuss, 1858 [= Prosopon aculeatum von Meyer, 1860]) in having a more elongate carapace (L/W 1.4 for Bajoprosopon n. gen. vs 1.24 for Europrosopon; both measured without rostrum), regions anterior of branchial groove with low tubercles, and orbits more anteriorly directed (vs anterolateral in Europrosopon).

Bajoprosopon n. gen. differs from Nipponopon (type: N. hasegawai Karasawa, Kato and Terabe, 2006; Barremian, Gunma Prefecture, Japan) in having a more elongate carapace (vs pyriform) with subparallel lateral margins, a weaker branchial condensation, a branchial groove that is more divergent, and subparallel to the cervical groove. Nipponopon and Rathbunopon in particular are morphologically close. Karasawa et al. (2006, p. 345) described the differences as follows, "... the carapace is slightly wider than long and triangular in outline, the protogastric region bears three pointed tubercles, the cervical groove is complete and deep, and the urogastric region is weakly bilobed and is not ornamented with two transverse ridges." The original material appears to be slightly compressed and additional specimens are needed for a more reliable reconstruction and comparison with Rathbunopon and other prosopids.

Bajoprosopon $\mathrm{n}$. gen. differs from Prosopon (type: P. tuberosum von Meyer, 1840) in having a less pyriform carapace (i.e., sides more subparallel), in lacking inflated epibranchial and hepatic bulges on lateral flanks, in having anteriorly, rather than anterolaterally, directed orbits, in possessing tubercular anterior regions and a weaker branchial condensation (i.e., cervical and branchial grooves further apart).

Bajoprosopon n. gen. differs from Protuberosa (type: Prosopon protuberosum Wehner, 1988) by the same characters as listed for Prosopon. In addition, Bajoprosopon n. gen. can be differentiated from Protuberosa in having coarse tubercles on regions anterior to branchial groove, a subhorizontal orbital margin (rather than an oblique one), and in having substraight lateral margins instead of clearly constricted ones in epibranchial regions.

Bajoprosopon n. gen. differs from Rathbunopon (type: R. polyakron) in having a more elongate carapace, not pyriform in outline (i.e., having subparallel lateral margins instead of convergent ones) and in having a weaker branchial condensation.

Of other primitive and coeval forms, Bajoprosopon n. gen. differs from Laeviprosopon (type: Prosopon laeve von Meyer, 1860, by original designation) in lacking a linea homolica (as far as can be observed in the sole known specimen; a linea homolica is not present in all specimens of Laeviprosopon, as N. Starzyk and colleagues will document shortly [work underway]), in having a projected, wide, and normal front (non-projecting, trifurcate in Laeviprosopon) and in having welldelineated, deep orbital fossae. The posterior margin (simple and concave in Laeviprosopon) is unfortunately not preserved in Bajoprosopon $\mathrm{n}$. gen., it could be another distinguishing character. The new genus differs from Homolus (type: $H$. auduini Eudes-Deslongchamps, 1835, Bathonian, Ranville, Calvados, France) in having a much weaker branchial condensation (i.e., branchial groove well distant from cervical groove), branchial groove subparallel to cervical groove (branchial groove more $\mathrm{V}$-shaped, under steeper angles than cervical groove, in Homolus), as well as by having well-delineated orbital fossae (undefined, protected by coarse spines, in Homolus). Unfortunately, the front is damaged in the single available specimen of Bajoprosopon piardi n. gen. and sp. In view of the fact that the orbits are of a morphologically similar construction to that of prosopids, the front may have been closer to that of prosopids than to the bifurcate one in Homolus and homolodromiids.

Eoprosopon (type and sole known species: $E$. klugi Förster, 1986) has a different groove pattern: the cervical groove is not formed of three arcs, but rather takes the form of a wide, continuous ' $V$ '; in addition, the branchial groove is parallel to the cervical groove. For further details, see above.

\section{Bajoprosopon piardi n. sp. Figure 4}

zoobank.org/FA2E987F-2D13-4BB1-BCA1-49C5676B4EDC

Material. A single dorsal carapace, MAB k.3764 (maximum carapace length, excluding rostrum = $12.2 \mathrm{~mm}$, maximum carapace width $=8.7 \mathrm{~mm}$ ) from the upper Bajocian 'Oolithe ferrugineuse de Bayeux' Formation (upper garantiana ammonite Zone, dichotoma ammonite Subzone), collected by 


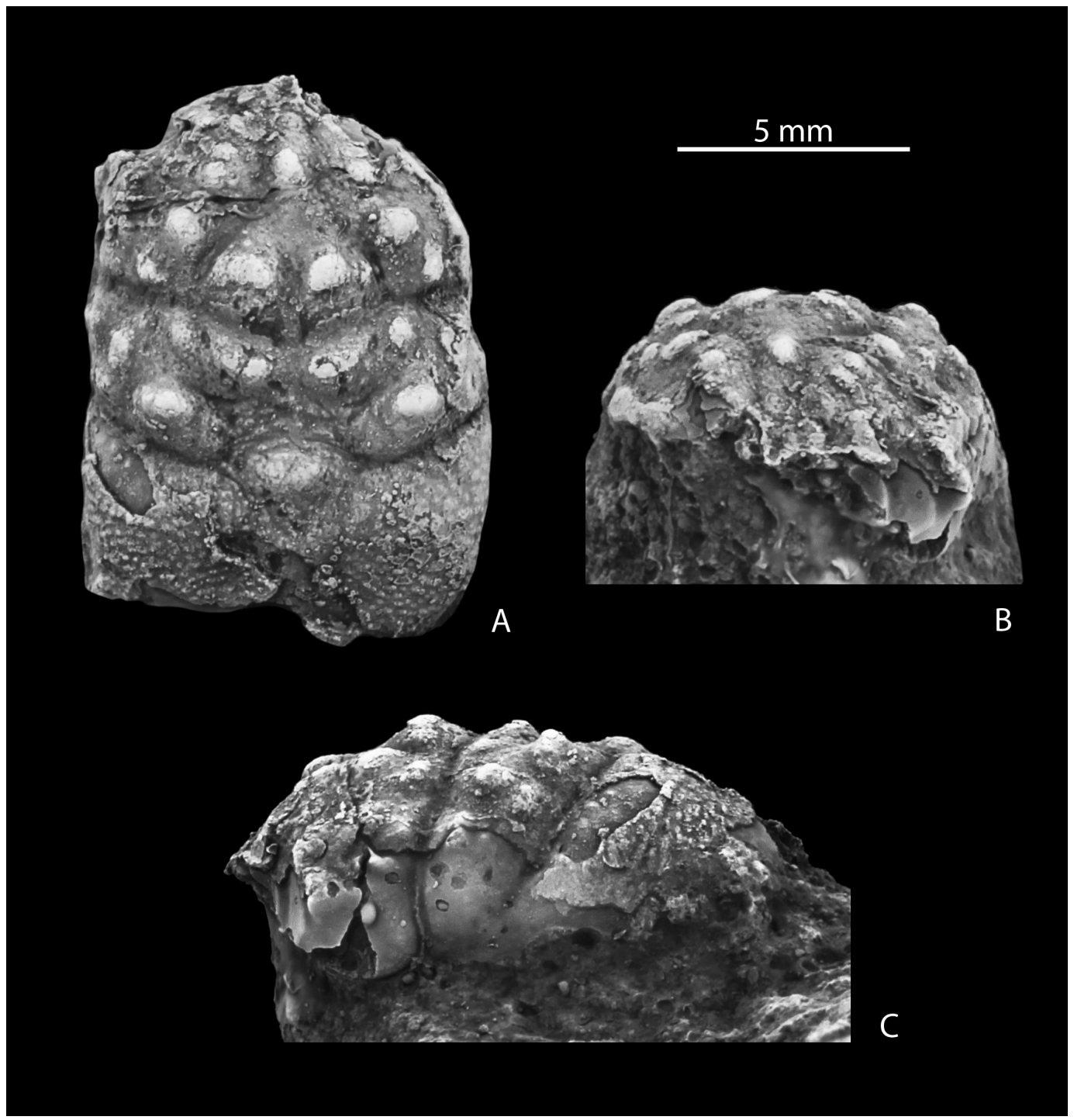

FIGURE 4. Holotype of Bajoprosopon piardi n. gen. and sp. (MAB k.3764) from the upper Bajocian 'Oolithe ferrugineuse de Bayeux' Formation (upper garantiana ammonite Zone, dichotoma ammonite Subzone) at the 'Les Fours à Chaux' outcrop between Croisilles and Les Moutiers-en-Cinglais (Calvados, France; Figure 1). A, dorsal view of carapace. B, frontal view of carapace. C, left lateral view of carapace. Scale bar equals $5 \mathrm{~mm}$.

one of us (LM) at the 'Les Fours à Chaux' outcrop between Croisilles and Les Moutiers-en-Cinglais (Calvados, France). It is preserved for the most part as an internal mould, but portions of cuticle remain.

Derivation of name. The species is named after the late Serge Piard, researcher and fossil collector, and good friend of one of us (LM).

Description. Carapace elongate, longer than wide, L/W approximately 1.40 (excluding rostrum), widest in branchial regions about one third of carapace length from posterior; convex in longitudinal and transverse cross-sections. Dorsal carapace regions well marked by grooves, with large tubercles, cuticle with granules. Rostrum partially pre- served, only proximal portion remaining and appearing wide. Orbitofrontal margin occupying entire anterior carapace width, orbital fossae conspicuously large, directed anteriorly, suboval, well delineated, with interior arched rim; outer orbital corner sharp. Lateral carapace margins arched, notched at cervical and branchial grooves. Posterior margin wide, but poorly preserved. Epigastric regions as small nodes; protogastric regions with three tubercles parallel to mesogastric lateral margin, median tubercle largest; mesogastric region with narrow and pointed anterior process, bearing small central tubercle, posterior mesogastric portion large, widely subtriangular, with two large, horizontally lined tubercles. Urogastic region weakly 
delineated, rather low, with two widened tubercles at same level as tubercles on posterior mesogastric region, and two weaker tubercles laterally. Epibranchial regions oblique, with large tubercle halfway, near branchial groove, and two smaller tubercles near lateral margin. Cardiac region relatively small, diamond shaped, apex directed posteriorly, with large, low central swelling. Cervical groove complete, composed of three portions; lateral portions rather short, weakly arched; central portion as wide $\mathrm{V}$, medially interrupted by shallow gastric pits. Branchial grooves distinct, slightly arched, subparallel to cervical groove; branchiocardiac grooves strongly arched. Posterior branchial region large, undifferentiated, weakly inflated. Remarks. In view of its superficially similar appearance, Bajoprosopon piardi n. gen. and sp. can be compared with Homolus auduini from the Bathonian at Ranville (Calvados, France). The most obvious differences are the branchial condensation and undefined/weakly defined orbits in Homolus, as described above. Of ornamentation, there is only a single protogastric spiniform tubercle in Homolus auduini, while there is a row with three blunt protogastric tubercles in Bajoprosopon piardi n. gen. and sp. Also, there are distinct epibranchial tubercles in Bajoprosopon piardi n. gen. and sp., which are missing from the reduced epibranchial region in Homolus auduini.

\section{DISCUSSION}

Guinot (2019, p. 749) stressed that palaeontologists had to work with a "shape-based categorization process" when only carapaces are known, from the fossil record; this is the case for virtually all Jurassic crabs. She also remarked that the Prosopidae was, "... certainly in need of a more detailed study" (p. 775) and "... probably not monophyletic and must be probably restricted" (p. 784). Thorough diagnoses are thus called for, both of families and genera, and proxy characters need to be carefully selected after studies with in-depth morphological comparisons.

The W-shaped (sinuous, or biconvex) posterior carapace margin in the Prosopidae needs to be commented upon. The median portion of this margin, i.e., the concave, inverted V-shaped part, corresponds to the adjacent first pleonal somite. The laterally divergent portions present space for the reduced last pereiopod, or the last pair of reduced pereiopods (compare Tavares and Lemaitre, 2014, figure $1 \mathrm{~A}$ with $1 \mathrm{~B}$ ). This is not similar to the lateral 'flange' of the Archaeochiapasidae Guinot, CarbotChanona and Vega, 2019, which morphologically more closely resembles the configuration seen in dorippids (for further details, see Wallaard et al., in press). In the genus Protuberosa Schweitzer and Feldmann, 2009, this sinuous posterior margin is also present (see also Wehner, 1988, pl. 1, figures 3,4 ), and it is similar in Homolodromia (compare Guinot, 1995, figure 8A) as well.

The orbits in members of the family Prosopidae constitute an important structure, which has often been misinterpreted by previous authors. Schweitzer and Feldmann (2009, p. 61), introduced the term 'augenrest', but failed to provide a diagnostic definition. As a result, this term has subsequently been applied to several types of structures. Recently, Klompmaker et al. (2020, p. 19) have argued that differences in the orbital structure "...appear less prominent than proposed"; we agree. There are several types of orbital structure. Most dynomeniform crabs have a completely defined orbit, i.e., a delineated orbital fossa. In other primitive Jurassic crabs there is an undefined orbit, which has been named 'false orbit' by Wright and Collins (1972, p. 43), 'plage orbitaire' by Guinot and Richer de Forges (1995, p. 303), or 'orbital area' by Guinot (2019, p. 752). In extant crabs this is the typical orbital construction in the superfamily Homoloidea $\mathrm{H}$. Milne Edwards, 1837; in the fossil record there may be more groups with this configuration. Previous misinterpretations of the orbital structure can also be linked to the previous inclusion of the genus Laeviprosopon Glaessner, 1933 in the Prosopidae.

There is a general consensus that the Prosopidae should be included in the Homolodromioidea (Wright and Collins, 1972; Wehner, 1988; Müller et al., 2000; Schweitzer and Feldmann, 2009; Jagt et al., 2015; Guinot, 2019). The family ranks amongst the oldest brachyuran groups, together with the Tanidromitidae (Fraaije et al., 2013; Krobicki and Zatoń, 2016). Based solely on carapace morphology, differences between homolodromiids and prosopids are few. Prosopids have a wide, subrectangular, or subtrapezoidal front (vs bifurcate in homolodromiids), and the dorsal carapace surface is divided into inflated regions (vs smooth and undivided in homolodromiids). In addition, prosopids typically have a granular dorsal carapace, with anterior regions often bearing central tubercles or low nodes, while homolodromiid carapaces tend to be rather smooth.

Bajoprosopon piardi $\mathrm{n}$. gen. and sp. is the oldest prosopid known to date. The stratigraphical range of the family is Middle Jurassic (Bajocian: Bajoprosopon piardi n. gen.and sp. and Prosopon 
TABLE 1. Members of the family Prosopidae von Meyer, 1860.

\begin{tabular}{|c|c|c|c|c|}
\hline Genus & Species & $\begin{array}{c}\text { Originally described and } \\
\text { synonymy }\end{array}$ & Age & Provenance \\
\hline $\begin{array}{l}\text { Acareprosopon } \\
\text { Klompmaker, } 2013\end{array}$ & $\begin{array}{l}\text { Acareprosopon bouvieri (Van } \\
\text { Straelen, 1944) }\end{array}$ & Pithonoton bouvieri & upper Albian & $\begin{array}{l}\text { Monte Orobe, Navarra } \\
\text { (northern Spain) }\end{array}$ \\
\hline Bajoprosopon n. gen. & $\begin{array}{l}\text { Bajoprosopon piardi n. gen. } \\
\text { and sp. }\end{array}$ & N.A. & Bajocian & $\begin{array}{l}\text { Calvados (northwest } \\
\text { France) }\end{array}$ \\
\hline \multirow{2}{*}{$\begin{array}{l}\text { Europrosopon } \\
\text { Klompmaker, Starzyk, } \\
\text { Schweigert and Fraaije, } \\
2020\end{array}$} & $\begin{array}{l}\text { Europrosopon abbreviatum } \\
\text { (Schweitzer and Feldmann, } \\
\text { 2009) }\end{array}$ & Prosopon abbreviatum & Tithonian & Ernstbrunn (Austria) \\
\hline & $\begin{array}{l}\text { Europrosopon verrucosum } \\
\text { (Reuss, 1858) (Type of } \\
\text { Genus) }\end{array}$ & $\begin{array}{l}\text { Prosopon verrucosum (= } \\
\text { Prosopon aculeatum von } \\
\text { Meyer, 1860; Prosopon } \\
\text { barbulescuae Schweitzer, } \\
\text { Feldmann, Lazăr, } \\
\text { Schweigert and Franţescu, } \\
2018)\end{array}$ & $\begin{array}{l}\text { Tithonian } \\
\text { Kimmeridgian }\end{array}$ & $\begin{array}{l}\text { Austria, Czech } \\
\text { Republic and Romania } \\
\text { southern Germany }\end{array}$ \\
\hline $\begin{array}{l}\text { Nipponopon Karasawa, } \\
\text { Kato and Terabe, } 2006\end{array}$ & $\begin{array}{l}\text { Nipponopon hasegawai } \\
\text { Karasawa, Kato and Terabe, } \\
2006\end{array}$ & N.A. & Barremian & $\begin{array}{l}\text { Gunma Prefecture } \\
\text { (Japan) }\end{array}$ \\
\hline \multirow[t]{4}{*}{$\begin{array}{l}\text { Prosopon von Meyer, } \\
1840\end{array}$} & $\begin{array}{l}\text { Prosopon jocosum } \\
\text { Thurmann in Étallon, } 1861\end{array}$ & N.A. & Kimmeridgian & Switzerland \\
\hline & $\begin{array}{l}\text { Prosopon josephcollinsi } \\
\text { Klompmaker, Starzyk, } \\
\text { Fraaije and Schweigert, } \\
2020\end{array}$ & N.A. & Tithonian & Ernstbrunn (Austria) \\
\hline & $\begin{array}{l}\text { Prosopon mammillatum } \\
\text { Woodward, } 1868\end{array}$ & N.A. & Bathonian & $\begin{array}{l}\text { Oxfordshire (United } \\
\text { Kingdom) }\end{array}$ \\
\hline & $\begin{array}{l}\text { Prosopon tuberosum von } \\
\text { Meyer, } 1840 \text { (Type of Genus) }\end{array}$ & N.A. & $\begin{array}{l}\text { Berriasian- } \\
\text { Hauterivian }\end{array}$ & $\begin{array}{l}\text { Département Jura } \\
\text { (France) }\end{array}$ \\
\hline $\begin{array}{l}\text { Protuberosa Schweitzer } \\
\text { and Feldmann, } 2009\end{array}$ & $\begin{array}{l}\text { Protuberosa protuberosa } \\
\text { (Wehner, 1988) }\end{array}$ & Prosopon protuberosum & Kimmeridgian & $\begin{array}{l}\text { Saal (southern } \\
\text { Germany) }\end{array}$ \\
\hline \multirow[t]{6}{*}{$\begin{array}{l}\text { Rathbunopon Stenzel, } \\
1945\end{array}$} & $\begin{array}{l}\text { Rathbunopon obesum (Van } \\
\text { Straelen, 1944) }\end{array}$ & Homolopsis obesa & upper Albian & $\begin{array}{l}\text { Monte Orobe, Navarra } \\
\text { (northern Spain) }\end{array}$ \\
\hline & $\begin{array}{l}\text { Rathbunopon oblitum } \\
\text { (Carter, 1898) }\end{array}$ & Mithracia oblita & Albian & $\begin{array}{l}\text { Cambridge (United } \\
\text { Kingdom) }\end{array}$ \\
\hline & $\begin{array}{l}\text { Rathbunopon polyakron } \\
\text { Stenzel, } 1945 \text { (Type of } \\
\text { Genus) }\end{array}$ & N.A. & Cenomanian & Texas (USA) \\
\hline & $\begin{array}{l}\text { Rathbunopon } \\
\text { schrattenkalkensis } \\
\text { Klompmaker, Artal and } \\
\text { Gulisano, } 2011\end{array}$ & N.A. & Aptian & Austria \\
\hline & $\begin{array}{l}\text { Rathbunopon tuberculatum } \\
\text { (Van Straelen, 1936) }\end{array}$ & Homolopsis tuberculata & Hauterivian & $\begin{array}{l}\text { Auxerre (southern } \\
\text { France) }\end{array}$ \\
\hline & $\begin{array}{l}\text { Rathbunopon woodsi } \\
\text { Withers, } 1951\end{array}$ & N.A. & Cenomanian & $\begin{array}{l}\text { Devonshire (United } \\
\text { Kingdom) }\end{array}$ \\
\hline
\end{tabular}

mammillatum Woodward, 1868) to mid-Cretaceous (Cenomanian: Rathbunopon woodsi Withers, 1951 and $R$. polyakron [Stenzel, 1945]), with numerous Jurassic members having been recorded from sponge-coral reef environments (Schweitzer and Feldmann, 2009; Klompmaker et al., 2020) (see also Table 1). Morphologically, the new genus appears closest to Prosopon, based on the weak branchial condensation, i.e., the clear separation of branchial and cervical grooves, considered to be a basal condition. The weak branchial condensation is linked to a basal condition in brachyurans (for discussion see Van Bakel et al., 2020, p. 13). A more elongate carapace is another basal condition that is seen in both Bajoprosopon n. gen. and Prosopon. 


\section{PALAEOECOLOGY}

Oolites of the 'Oolithes ferrugineuses de Bayeux' are spherical and vary in size; in the garantiana ammonite Zone they are of medium size, measuring 0.3-0.4 mm in diameter. Structurally, they consist of a core of mineral origin (either a lithoclast or bioclast), which is covered by thin concentric ferruginous layers. These oolites formed in a shallow, yet agitated, marine environment, initially in suspension and subsequently landed on the seafloor. As noted above, Middle Jurassic crabs are rare, but most occurrences are from oolitic rock types. Krobicki and Záton (2016) reviewed the palaeoenvironment of Middle Jurassic crabs; they recognised $(2016$, p. 711) a "Brachyuran Bajocian Expansion Event" with appearance of new species in shallow water environments and linked this to the distribution of e.g., oolitic and iron-ooidal and/or bioclastic facies of shallow-water, high-energy environments. These authors concluded (2016, p. 695) that "... during the first step in the origin of true crabs they were connected with shallow, marine, high-energy carbonate deposits dominated by oolitic (including ferrugineus-oolitic one) facies, coralliferous reefs, and grey/black clays with carbonate concretions." At present, it is unclear if there is a direct palaeoecological connection or if such levels are simply the commonest and most intensively sampled of Middle Jurassic strata.

\section{ACKNOWLEDGEMENTS}

We thank D. Guinot (MNHN, Paris) for helpful discussions on von Meyer's authorship dates and the journal reviewers, Carrie E. Schweitzer (Kent State University, Ohio, USA) and two anonymous reviewers, for much appreciated comments on a previous version of the typescript.

\section{REFERENCES}

Agassiz, L. and Desor, P.J.E. 1847. Catalogue raisonné des familles, des genres, et des espèces de la classe des échinodermes. Annales des Sciences naturelles (3. Zoologie), 8:535, 355-380.

Alcock, A. 1900. Materials for a carcinological fauna of India, No. 5. The Brachyura Primigenia or Dromiacea. Journal of the Asiatic Society of Bengal, 68:123-169.

Bentz, A. 1928. Über Strenoceraten und Garantianen insbesondere aus dem mittleren Dogger von Bielefeld. Jahrbuch der Preußischen Geologischen Landesanstalt, 49:138-206.

Beurlen, K. 1928. Die fossilen Dromiaceen und ihre Stammesgeschichte. Palaeontologische Zeitschrift, 10:144-183.

Breton, G., Jäger, M., and Kočí, T. 2020. The sclerobionts of the Bajocian Oolithe ferrugineuse de Bayeux Formation from Calvados (Paris Basin, Normandy, France). Annales de Paléontologie, 106:102361. https://doi.org/10.1016/j.annpal.2019.07.002

Carter, J. 1898. A contribution to the palaeontology of the decapod Crustacea of England. The Quarterly Journal of the Geological Society of London, 54:15-44.

Collins, J.S.H. and Wierzbowski, A. 1985. Crabs from the Oxfordian sponge megafacies of Poland. Acta Geologica Polonica, 35:73-88.

Deshayes, G.P. 1831. Description de coquilles caractéristiques des terrains. F.G. Levrault, Paris.

Deslongchamps, J.A. 1848. Mémoire sur les Pleurotomaires des terrains secondaires du Calvados, suivi d'une note sur une espèce d'Oscabrion fossile des mêmes terraines, et de suppléments aux mémoires sur les genres Ombrelle, Bulle, Tornatelle et Cone. Mémoires de la Société linnéenne de Normandie, 8:1-166.

Donovan, D.T. 1962. New examples of the fossil crab Pithonoton from the Inferior Oolite of Gloucestershire and Somerset. Proceedings of the Geologists' Association, 73:193-196. https://doi.org/10.1016/S0016-7878(62)80004-2

Étallon, A. 1861. Note sur les Crustacés jurassiques du bassin du Jura. Mémoires de la Société d'Agriculture de Haute-Saône, 9:129-171.

Eudes-Deslongchamps, J.A. 1835. Mémoire pour server à l'histoire naturelle des Crustacés fossiles. Mémoires de la Société linnéenne de Normandie, 5:37-46.

Förster, R. 1979. Eocarcinus praecursor Withers (Decapoda, Brachyura) from the lower Pliensbachian of Yorkshire and the early crabs. Neues Jahrbuch für Geologie und Paläontologie, Monatshefte, 1979(1):15-27. 
Förster, R., 1985. Evolutionary trends and ecology of Mesozoic decapod crustaceans. Transactions of the Royal Society of Edinburgh, Earth and Environmental Science, 76:299304. https://doi.org/10.1017/S0263593300010518

Förster, R. 1986. Der erste Nachweis eines brachyuren Krebses aus dem Lias (oberes Pliensbach) Mitteleuropas. Mitteilungen aus der Bayerischen Staatssammlung für Paläontologie und historische Geologie, 26:25-31.

Fraaije, R.H.B., Van Bakel, B.W.M., Guinot, D., and Jagt, J.W.M. 2013. A new Middle Jurassic (Bajocian) homolodromioid crab from northwest France; the earliest record of the Tanidromitidae. Boletín de la Sociedad Geológica Mexicana, 65:249-254.

Glaessner, M.F. 1933. Die Krabben der Juraformation. Zentralblatt für Mineralogie, Geologie und Paläontologie, Abteilung B, 1933:178-191.

Goldfuss, A. 1833-1841. Petrefacta Germaniae, 2. Arnz \& Co., Düsseldorf.

Guinot, D. 1977. Propositions pour une nouvelle classification des Crustacés Décapodes Brachyoures. Comptes Rendus hebdomadaires des Séances de l'Académie des Sciences, D285:1049-1052.

Guinot, D. 1995. Crustacea, Decapoda, Brachyura: Révision des Homolodromiidae Alcock, 1900. In Crosnier, A. (ed.), Résultats des campagnes MUSORSTOM, Volume 13. Mémoires du Muséum national d'Histoire naturelle Paris, 163:155-282.

Guinot, D. 2019. New hypotheses concerning the earliest brachyurans (Crustacea, Decapoda, Brachyura). Geodiversitas, 41:747-796. https://doi.org/10.5252/geodiversitas2019v41a22

Guinot, D., Carbot-Chanona, G., and Vega, F.J. 2019. Archaeochiapasidae n. fam., a new early Cenomanian brachyuran family from Chiapas, Mexico, new insights on Lecythocaridae Schweitzer and Feldmann, 2009, and phylogenetic implications (Crustacea, Decapoda, Brachyura, Eubrachyura). Geodiversitas, 41:285-322. https://doi.org/10.5252/ geodiversitas2019v41a7

Guinot, D. and Richer de Forges, B. 1995. Crustacea, Decapoda, Brachyura: révision de la famille des Homolidae de Haan, 1841. In Crosnier A. (ed.), Résultats des Campagnes MUSORSTOM. Vol. 13. Mémoires du Muséum national d'Histoire naturelle Paris, 163:283517. https://biodiversitylibrary.org/page/58815176

Guinot, D, Tavares, M., and Castro, P. 2013. Significance of the sexual openings and supplementary structures on the phylogeny of brachyuran crabs (Crustacea, Decapoda, Brachyura), with new nomina for higher-ranked podotreme taxa. Zootaxa, 3665:1-414. https:/ /doi.org/10.11646/zootaxa.3665.1.1

Haug, J.T. and Haug, C. 2014. Eoprosopon klugi (Brachyura) - the oldest unequivocal and most "primitive" crab reconsidered. Palaeodiversity, 7:149-158.

Hée, A. 1924. Catalogue critique des Crustacés jurassiques du Calvados et de l'Orne. Bulletin de la Société linnéenne de Normandie, 7(6):126-157.

ICZN 1999. International Code of Zoological Nomenclature, Fourth Edition. International Trust for Zoological Nomenclature, London.

Jagt, J.W.M., Van Bakel, B.W.M., Guinot, D., Fraaije, R.H.B., and Artal, P. 2015. Fossil Brachyura, p. 847-920. In Castro, P., Davie, P.J.F., Guinot, D., Schram, F., and Von Vaupel Klein, C. (eds.), Treatise on zoology - anatomy, taxonomy, biology - the Crustacea, complementary to the volumes translated from the French of the Traite de Zoologie $9(\mathrm{C})(\mathrm{I})$, Decapoda: Brachyura (Part 1). E.J. Brill, Leiden. https://doi.org/10.1163/ 9789004190832_018

Jester, C.D. 2017. Origin and paleoecology of ferruginous oncoids ("snuff-boxes") of the Middle Jurassic (Bajocian) in the Inferior Oolite Group of southern England and northern France. Senior Independent Study Theses, Paper 7766. The College of Wooster. https://openworks.wooster.edu/independentstudy/7766/

Karasawa, H., Kato, H., and Terabe, K. 2006. A new member of the Family Prosopidae (Crustacea: Decapoda: Brachyura) from the Lower Cretaceous of Japan. Revista Mexicana de Ciencias Geológicas, 23:344-349.

Klompmaker, A.A. 2013. Extreme diversity of decapod crustaceans from the mid-Cretaceous (late Albian) of Spain: implications for Cretaceous decapod paleoecology. Cretaceous Research, 41:150-185. https://doi.org/10.1016/j.cretres.2012.12.003

Klompmaker, A.A., Artal, P., and Gulisano, G. 2011. The Cretaceous crab Rathbunopon: revision, a new species and new localities. Neues Jahrbuch für Geologie und Paläontologie Abhandlungen, 260:191-202. https://doi.org/10.1127/0077-7749/2011/0170 
Klompmaker, A.A., Starzyk, N., Fraaije, R.H.B., and Schweigert, G. 2020. Systematics and convergent evolution of multiple reef-associated Jurassic and Cretaceous crabs (Decapoda, Brachyura). Palaeontologia Electronica, 23:a32. https://doi.org/10.26879/1045

Krobicki, M. and Zatoń, M. 2008. Middle and Late Jurassic roots of brachyuran crabs: palaeoenvironmental distribution during their early evolution. Palaeogeography, Palaeoclimatology, Palaeoecology, 263:30-43. https://doi.org/10.1016/j.palaeo.2008.01.025

Krobicki, M. and Zatoń, M. 2016. A new homolodromioid crab (Brachyura: Dromiacea: Tanidromitidae) from the Bajocian of central Poland and a review of the stratigraphical distribution and paleoenvironments of the known Middle Jurassic homolodromioids. Journal of Crustacean Biology, 36:695-715. https://doi.org/10.1163/1937240X-00002463

Lamarck, J.B. 1818-1819. Histoire naturelles des animaux sans vertèbres, 5(1818):1-612; 6(1819):1-343. Verdière, Paris.

Latreille, P.A. 1802. Histoire naturelle, générale et particulière, des crustacés et des insectes, 3. F. Dufart, Paris.

Linnaeus, C. 1758. Systema naturae per regna tria naturae, secundum classes, ordines, genera, species, cum characteribus, differentiis, synonymis, locis (Editio decima), 1. Laurentius Salvius, Holmiae.

Luque, J., Feldmann, R.M., Vernygora, O., Schweitzer, C.E., Cameron, C.B., Kerr, K.A., Vega, F.J., Duque, A., Strange, M., Palmer, A.R., and Jaramillo, C. 2019. Exceptional preservation of mid-Cretaceous marine arthropods and the evolution of novel forms via heterochrony. Science Advances, 5:eaav3875. https://doi.org/10.1126/sciadv.aav3875

Milne Edwards, H. 1837. Histoire naturelle des crustacés comprenant l'anatomie, la physiologie et la classification de ces animaux. Librairie Encyclopédique de Roret, Paris, 2:1-531. https:/ /doi.org/10.5962/bhl.title.16170

Müller, P., Krobicki, M., and Wehner, G. 2000. Jurassic and Cretaceous primitive crabs of the family Prosopidae (Decapoda: Brachyura) - their taxonomy, ecology and biogeography. Annales Societatis Geologorum Poloniae, 70:49-79.

Patrulius, D. 1966. Les décapodes du Tithonique Inférieur de Woźniki (Carpathes Polonaises Occidentales). Annales de la Société géologique de Pologne, 36:495-517.

Pavia, G. and Martire, L. 2010. Indirect biostratigraphy in condensed successions: a case history from the Bajocian of Normandy (NW France). Volumina Jurassica, 7:67-76.

Pavia, G., Defaveri, A., Maerten, L., Pavia, M., and Zunino, M. 2013. Ammonite taphonomy and stratigraphy of the Bajocian at Maizet, south of Caen (Calvados, NW France). Comptes Rendus Palevol, 12:137-148. https://doi.org/10.1016/j.crpv.2013.03.001

Pavia, G., Corbin, L., Defaveri, A., Maerten, L., and Olivero, D. 2015. La formation de l'Oolithe ferrugineuse de Bayeux du Bajocien (Jurassique moyen) au lieu-dit «Les fours à chaux» entre Croisilles et les Moutiers-en-Cinglais (Calvados, NW France). Géologie de la France, 2:5-20.

Reuss, A.E. 1858. Über kurzschwänzige Krebse im Jurakalke Mährens. Sitzungsberichte der kaiserlichen Akademie der Wissenschaften zu Wien, mathematisch-naturwissenschaftliche Classe, 31:5-13.

Scholtz, G. 2020. Eocarcinus praecursor Withers, 1932 (Malacostraca, Decapoda, Meiura) is a stem group brachyuran. Arthropod Structure and Development, 59:100991. https://doi.org/ 10.1016/j.asd.2020.100991

Schweigert, G. 2006. A specimen of Prosopon hebes v. Meyer, 1840 (Decapoda: Brachyura: Prosopidae) from the Middle Jurassic of SW Germany. Neues Jahrbuch für Geologie und Paläontologie, Monatshefte, 2006(6):361-370. https://doi.org/10.1127/njgpm/2006/2006/361

Schweigert, G. and Koppka, J. 2011. Decapods (Crustacea: Brachyura) from the Jurassic of Germany and Lithuania, with descriptions of new species of Planoprosopon and Tanidromites. Neues Jahrbuch für Geologie und Paläontologie Abhandlungen, 260:221-235. https://doi.org/10.1127/0077-7749/2011/0136

Schweitzer, C.E. and Feldmann, R.M. 2008. Revision of the genus Laeviprosopon Glaessner, 1933 (Decapoda: Brachyura: Homolodromioidea: Prosopidae) including two new species. Neues Jahrbuch für Geologie und Paläontologie Abhandlungen, 250:273-285. https://doi.org/ 10.1127/0077-7749/2008/0250-0273

Schweitzer, C.E. and Feldmann, R.M. 2009. Revision of the Prosopinae sensu Glaessner, 1969 (Crustacea: Decapoda: Brachyura) including four new families, four new genera, and five new species. Annalen des Naturhistorischen Museums in Wien, A110:55-121. 
Schweitzer, C.E. and Feldmann, R.M. 2010. The oldest Brachyura (Decapoda:

Homolodromioidea: Glaessneropsoidea) known to date (Jurassic). Journal of Crustacean Biology, 30:251-256. https://doi.org/10.1651/09-3231.1

Schweitzer, C.E., Feldmann, R.M., and Karasawa, H. 2012. Part R, Revised, Volume 1, Chapter 8M: Systematic descriptions: Infraorder Brachyura, Section Dromiacea. Treatise Online, 51:1-43. https://doi.org/10.17161/to.v0i0.4336

Schweitzer, C.E., Feldmann, R.M., Lazăr, I., Schweigert, G., and Franţescu, O.D. 2018. Decapoda (Anomura; Brachyura) from the Late Jurassic of the Carpathians, Romania. Neues Jahrbuch für Geologie und Paläontologie Abhandlungen, 288:307-341. https://doi.org/ 10.1127/njgpa/2018/0744

Smith, W. 1816-1819. Strata Identified by Organized Fossils, Containing Prints and Coloured Paper Illustrations of the Most Characteristic Specimens in Each Stratum. Aarding, London.

Sowerby, J. 1812-1829. The Mineral Conchology of Great Britain, Volumes 1-6. The author, London.

Starzyk, N. 2020. The oldest species of the genus Laeviprosopon (Decapoda: Brachyura: Prosopidae) from the Oxfordian of Poland. Acta Zoologica Cracoviensia, 63:9-13. https:// doi.org/10.3409/azc.63.02

Stenzel, H.B. 1945. Decapod crustaceans from the Cretaceous of Texas. University of Texas Publications, 4401:401-476.

Tavares, M. and Lemaitre, R. 2014. New morphological and distributional information on Homolodromiidae and Homolidae (Decapoda: Brachyura) from the Americas, with description of a new species and comments on western Pacific species. Journal of Crustacean Biology, 34:504-524. https://doi.org/10.1163/1937240X-00002243

Van Bakel, B.W.M., Mychko, E.V., Spiridonov, A., Jagt, J.W.M., and Fraaije, R.H.B. 2020. New Cretaceous crabs (Crustacea, Brachyura) from Moscow Oblast and Dagestan (Russia): patterns in phylogeny and morphospace of the oldest eubrachyurans (Dorippoidea). Cretaceous Research, 119:104675. https://doi.org/10.1016/j.cretres.2020.104675

Van Straelen, V. 1925 (misdated 1924). Contribution à l'étude des crustacés décapodes de la période Jurassique. Mémoires de l'Académie royale de Belgique, Classe des Sciences, $7(2): 1-462$.

Van Straelen, V. 1936. Crustacés Décapodes nouveaux ou peu connus de l'époque Crétacique. Bulletin du Musée royal d'Histoire naturelle de Belgique, 12:1-49.

Van Straelen, V. 1944. Anomure et brachyures du Cénomanien de la Navarre. Bulletin du Musée royal d'Histoire naturelle de Belgique, 20:1-12.

von Meyer, H. 1835. [Briefliche Mittheilungen]. Neues Jahrbuch für Mineralogie, Geologie, Geognosie und Petrefaktenkunde, 1835:328-329.

von Meyer, H. 1840. Neue Gattungen fossiler Krebse aus Gebilden vom Bunten Sandsteine bis in die Kreide. E. Schweizerbart, Stuttgart.

von Meyer, H. 1857. [Briefliche Mittheilungen an Professor H. Bronn]. Neues Jahrbuch für Mineralogie, Geognosie, Geologie und Petrefaktenkunde, 1857:554-557.

von Meyer, H. 1860. Die Prosoponiden oder die Familie der Maskenkrebse. Palaeontographica, 7:183-222, 305.

Wallaard, J.J.W., Van Bakel, B.W.M., Fraaije, R.H.B., and Jagt, J.W.M. In press. A new homolodromioid crab from the Upper Jurassic of the Solnhofen Lagerstätte (southern Germany). Neues Jahrbuch für Geologie und Paläontologie Abhandlungen.

Wehner, G. 1988. Über die Prosoponiden (Crustacea, Decapoda) des Jura. Dissertation, Ludwig-Maximilians-Universität München, published by the author.

Withers, T.H. 1932. A Liassic crab, and the origin of the Brachyura. The Annals and Magazine of Natural History, 10:313-323. https://doi.org/10.1080/00222933208673499

Withers, T.H. 1951. Some Jurassic and Cretaceous crabs (Prosoponidae). Bulletin of the British Museum (Natural History) (Geology), 1:171-192.

Woodward, H. 1868. II.-On a new brachyurous crustacean (Prosopon mammillatum), from the Great Oolite, Stonesfield. Geological Magazine, 5:3-5. https://doi.org/10.1017/ S0016756800207140

Woodward, H. 1907. V.-On a new brachyurous crustacean from the "Clypeus-Grit" (Inferior Oolite) of the Cotteswold Hills. Geological Magazine, 4:79-81. https://doi.org/10.1017/ S0016756800120205

Wright, C.W. and Collins, J.S.H. 1972. British Cretaceous crabs. Monograph of the Palaeontographical Society London, 126(533):1-114. 